\title{
Postpartum Depression in Men
}

\author{
Sarah J. Breese McCoy \\ Oklahoma State University Center for Health Sciences \\ Tulsa, Oklahoma \\ USA
}

\section{Introduction}

Postpartum depression (PPD) is a form of major depressive disorder (MDD) and has traditionally been defined as occurring in women within three months to a year following childbirth (McCoy, 2011). However, this phenomenon has also been observed in men after their wives or partners give birth. The terminology used to described depression in males following the birth of a child has not yet been standardized. Some phrasing includes "paternal postpartum depression", and "postpartum psychiatric disorder, depressed mood, and distress" (Schumacher, 2008). For the purposes of this chapter, "paternal PPD" will be used. Although the research in men has been taking place for a much shorter time and with fewer patients than for women, valuable insights have already been gained.

\section{Epidemiology and etiology}

In any given year, about $3.3 \%$ of men experience general, true clinical depression, or MDD (Depression Facts and Statistics, 2009). Several attempts have been made to estimate the rate of paternal PPD, as well (Madsen \& Juhl, 2007; Paulson \& Bazemore, 2010; Lai, 2010). A meta-analysis of 43 studies from 16 countries estimated paternal PPD at 10.4\%, with the highest rate occurring about 3-6 months postpartum (Paulson \& Bazemore, 2010). That figure is suspiciously high, however, because the same analysis yielded an estimate of maternal PPD at 23.8\%, well above the accepted average of $13 \%$ (Pearlstein et al, 2009; Cuijpers et al, 2008). These higher values are probably due to the inclusion of cases that may actually be only minor depression, without sufficient symptoms to qualify as MDD (Paulson \& Bazemore, 2010). In fact, the true rate of paternal PPD may be closer to 5\% (Madsen \& Juhl, 2007). If paternal PPD were not a real phenomenon specifically related in some way to the birth of a child, the rate of men experiencing depression in the year following their children's birth would be expected not to exceed the 3.3\% MDD incidence for men each year. In other words, any depression men might be experiencing in the postpartum period would be truly independent of and merely coincident with the child's birth.

Several factors have been shown to be independent predictors of paternal PPD: past history of severe depression, prenatal depression, prenatal anxiety, lower education level, having other children, and maternal prenatal depression (Ramchandani, 2008). Further, one finding in particular seems very clear-PPD in women influences paternal PPD. In fact, when maternal depression is moderate to severe, the prevalence of paternal PPD has been 
reported to be over $40 \%$ (Veskrna, 2010). In that same vein, the authors of the previously mentioned meta-analysis (Paulson \& Bazemore, 2010) reached several useful conclusions: (1) Paternal PPD is a significant and real problem. (2) Rates are higher in the US than in other countries investigated, perhaps due to varying social norms or expectations. (3) Paternal PPD is correlated with maternal PPD.

Condon (2004) did a study at two teaching hospitals in Australia on 204 first-time fathers. Men were assessed using various mood and mental health scales at 23 weeks gestation, and at 3, 6, and 12 months after their partners gave birth. Interestingly, the fathers' greatest vulnerability to depression in the perinatal period was at the beginning of the third trimester of their partner's pregnancy, rather than after the birth. Although the authors admitted a possibility of sample bias, their results showed that expectant fathers were more likely to be depressed and irritable, had more somatic symptoms and even drank more alcohol than during the postpartum period. The reason for the fathers' stress and depression was apparently related to the anticipation of a decline in frequency of sex. Symptom measures were then relatively stable between 3 and 12 months postpartum. Another important finding was that during the first year postpartum, all significant relationship changes were in a negative direction between husband and wife, again, perhaps in large part from the men's point of view, because of decreasing frequency of sexual contact. Overall, however, the pregnancy itself was a more stressful time for men than the postnatal period (Condon et al, 2004).

\section{Manifestations and consequences of male PPD}

MDD in men and paternal PPD manifest somewhat differently than for women and may include such symptoms as hostility, conflict, and anger, rather than the more broadly recognized sadness or apathy (Table 1). In addition, men may self-medicate for their depression by drinking alcohol, and they may withdraw or engage in escape activities such as overwork, sports, sex, or gambling (Veskrna, 2010).

\begin{tabular}{|ll|}
\hline 1. & Anger attacks \\
\hline 2. & Affective rigidity (failure to express emotions) \\
\hline 3. & Self criticism \\
\hline 4. & Alcohol and drug abuse \\
\hline 5. & Unhealthy sexual relationships or infidelity \\
\hline 6. & Reckless behavior, such as unsafe driving \\
\hline 7. & Abusive behavior \\
\hline 8. & Escapist behavior, such as spending excessive time watching television or at work \\
\hline
\end{tabular}

Table 1. Possible Additional Symptoms of Major Depressive Disorder in Men*

${ }^{*}$ www.mayoclinic.com; Madsen and Juhl, 2007

New fathers may experience many of the same changes and stresses that new mothers do, such as sleep disruption, relationship conflicts, and/or financial strain. Because many new mothers work, society now expects men to work more at home and help more with the children than in the past. Yet, their forbears, on whom those expectations did not rest, cannot provide an appropriate model for how to do this difficult task. The resultant stress 
may predispose men to a greater risk of depression in the postpartum period than at other times in their lives (Veskrna, 2010).

The literature has begun to suggest that fathers influence their children's attitude and actions more than was previously understood (Veskrna, 2010). For example, a United Kingdom study of 10,975 fathers and their children followed the families from 18 weeks gestation to seven years of age. This study was free of selection biases, and was prospective, which, together with its large sample size, were key strengths. Fathers were assessed four times-at 18 weeks gestation, eight weeks postpartum, eight months postpartum and twenty-one months postpartum. Their children were assessed at ages six and seven years, using reports from both the mothers and schoolteachers. The depression screens used for fathers in the study were the Edinburgh Postnatal Depression Scale (EPDS) and the Crown Crisp Experiential Index for anxiety symptoms (Ramchandani et al, 2008). The researchers found that paternal PPD at 8 weeks postpartum was associated with psychiatric diagnoses in their children at age seven years. In fact, twice as many children of depressed fathers developed a psychiatric disorder as children of fathers who were not depressed. Paternal PPD was also associated with higher scores on tests that measured sociability (reverse scored), hyperactivity, conduct problems, and peer problems. The authors concluded that paternal PPD is strongly predictive of increased rates of psychiatric disorders, such as oppositional defiant or conduct disorder, as well as social difficulties (Ramchandani et al, 2008).

In summary, adverse consequences to the child make paternal PPD especially important to address. New fathers should be evaluated for depression, especially when it is known that the mother is suffering from PPD. More research in this area is needed (Schumacher et al, 2008).

\section{Making the diagnosis}

As a form of MDD, PPD has traditionally been diagnosed according to the same criteria for MDD that are laid out in the Diagnostic and Statistical Manual-IV (DSM IV) (American Psychiatric Association, 2000) (Table 2). For a definitive diagnosis, five of the nine possible symptoms must be present for a minimum of two weeks. Instead of specific tests for PPD, sometimes regular screens for detecting MDD are used to assess women after they give birth. These include such tools as the Beck Depression Inventory (BDI), Center of Epidemiologic Studies Depression Scale (CES-D), and the Patient Health Questionnaire (PHQ-9), among others. Although the BDI is protected by copyright that prevents its demonstration here, the CES-D and the PHQ-9 are provided at the end of this chapter as a point of reference (Appendices 1 and 2).

Generalized tests are still used in PPD research, but they may give artificially elevated scores, because they count sleep disturbance and changes in appetite as symptoms of depression. However, both of these experiences are normal during the postpartum period, even for women who are not depressed (Pearlstein et al, 2009).

The Edinburgh Postnatal Depression Scale (EPDS) was developed as a screen specifically for PPD in women and first published in the literature in 1987. It is a self-administered, tenquestion quiz in which participants rate how they have been feeling for the past week, 
selecting from four possible answers for each question. Each potential answer has a numerical value assigned to it, ranging from $0-3$. The highest possible score on the test is 30 , indicating the most depressive symptoms present. The lowest possible score is 0 , indicating the least depressive symptoms (Appendix 3). The authors originally suggested that a positive screen for PPD be $\geq 13$, for a demonstrated sensitivity and specificity of $86 \%$ and $78 \%$, respectively (Cox et al, 1987). The EPDS is now well-established for use in both the prenatal and postpartum periods in women (Sit \& Wisner, 2009) and has been translated into several languages.

\begin{tabular}{|ll|}
\hline $\begin{array}{l}\text { At least five of the following symptoms have been present during the same 2-week } \\
\text { period; at least one of the symptoms is either \#1 or \#2 }\end{array}$ \\
\hline 1. & Depressed mood \\
\hline 2. & Diminished interest or pleasure in activities \\
\hline 3. & Significant change in weight or appetite \\
\hline 4. & Insomnia or hypersomnia \\
\hline 5. & Psychomotor agitation or retardation \\
\hline 6. & Fatigue or loss of energy \\
\hline 7. & Feelings of worthlessness or excessive or inappropriate guilt \\
\hline 8. & Diminished ability to think or concentrate \\
\hline 9. & Recurrent thoughts of death, suicidal ideation, suicide attempt or specific plan for \\
& committing suicide \\
\hline
\end{tabular}

Table 2. Conventional Symptoms for Major Depressive Disorder in Men and Women* *American Psychiatric Association, 2000

Investigation of the EPDS for use in men originated in the early 1990s. However, those first studies tended to use the same 12/13 cut-off for a positive screen as was recommended for English-speaking women. Women of some cultures now have lower cutoffs on the EPDS than English-speaking women, because they don't tend to be as demonstrative. In the same way, it makes sense that a positive screen for depression in men might be a lower score on the EPDS than for women, because men tend to express fewer negative emotions than women in Western cultures (Matthey et al, 2001).

The EPDS has two questions that deal with anxiety, and, therefore, it might also be used to detect fear and anxiety disorders as well as depression. Matthey et al (2001) uses the term "caseness" to refer to people who take the EPDS and meet the criteria for major/minor depression, or for panic, or adjustment disorder with anxiety. Matthey's study (2001) was done at 6-7 weeks postpartum, and 208 men participated. Of the 208, eleven met the criteria for distress - three with only depression, three with both depression and anxiety, and five with just anxiety. The optimum cutoff for men was $5 / 6$, because with those values, $75 \%$ of distressed men and $69.8 \%$ of non-distressed men were correctly detected. False negatives were a mere $2.1 \%$. Although the false positive rate was $87.3 \%$ at this cutoff, the authors felt it was justified, due to the great need to detect men with these disorders. The authors concluded that the EPDS is reliable and valid for detecting postpartum distress in men. They recommend that it be used routinely in all new fathers, as it has been recommend for use with all new mothers (Matthey et al, 2001). 
In another investigation, 551 Chinese men were assessed with the EPDS and two other depression screens, the BDI and the Patient Health Questionnaire (PHQ-9), at eight weeks postpartum. The men's average age was about 33 years. The optimum cutoff score was set at $\geq 10$, rather than $\geq 13$ as recommended for English-speaking women. For a cutoff of 10/11, sensitivity was $91 \%$ and specificity was $97 \%$. The EPDS was found to be more accurate than the other two screening tests. One reason seems to be that the EPDS does not include questions about fatigue and sleep disturbances as symptoms of depression, because they are both normal and common in new parents. Results showed that Chinese men were less likely than women to seek help for depression, but the rate of $3.1 \%$ of men meeting the criteria for depression was about the same as the rate for Australian fathers in another study. The symptoms most likely to be reported in both depressed and nondepressed fathers were feelings of being overwhelmed and blaming themselves unduly when things went wrong. The authors concluded that the postnatal period appears to be a time when Chinese men are vulnerable to developing depressive symptoms (Lai et al, 2010).

Because recent research is demonstrating that MDD in men, and thus paternal PPD, may manifest somewhat differently than depression in women, other screening tools that take into account men's unique symptoms are sometimes employed. One example is the Gotland Male Depression Scale (GMDS) (Table 3 \& Appendix 4). Although it was not specifically designed for the postpartum period, its questions are engineered with the unique symptoms in mind of depression in males. Like the EPDS, the GMDS is selfadministered and relatively easy to use. A cutoff score of $\geq 13$ is recommended as a positive result for depression. The GMDS has thirteen items and has been validated (Zierau et al, 2002).

\begin{tabular}{|ll|}
\hline 1. & Lower stress threshold \\
\hline 2. & Aggression, low impulse control \\
\hline 3. & Feeling of being burned out or empty \\
\hline 4. & Constant, inexplicable fatigue \\
\hline 5. & Irritability, restlessness, dissatisfaction \\
\hline 6. & Difficulty making decisions \\
\hline 7. & Sleep problems \\
\hline 8. & Anxiety/ displeasure, especially in the morning \\
\hline 9. & Abusive or hyperactive behavior; changes in eating habits \\
\hline 10. & Antisocial behavior \\
\hline 11. & Depressive thoughts \\
\hline 12. & Increased tendency to complain \\
\hline 13. & Family history of depression, alcoholism, suicide \\
\hline
\end{tabular}

Table 3. Items Assessed in the Gotland Male Depression Scale (Madsen \& Juhl, 2007)

A 2007 Danish study of 549 fathers calculated the prevalence of depressive symptoms at six weeks postpartum, using both the EPDS and the GMDS. Although neither test picked up all the fathers that were at risk for PPD, the EPDS was positive for 27 men, while the GMDS was only positive for eighteen (Madsen \& Juhl, 2007). Ultimately, at this time there is no 
single ideal screening test for PPD in men, but the EPDS is probably the best tool available to date.

\section{Treatment options}

The standard of care for MDD in general continues to be antidepressants, psychotherapy, or both (McCoy, 2011). Paternal PPD is no exception. However, convincing men to seek help when they are depressed can be a challenge. Men are more likely to agree to psychotherapy if that option is presented as a way to protect or restore some aspect of their masculinity, as in the ability to provide for the family or contribute to the family's well-being (Veskrna, 2010).

Fletcher et al (2006) has listed some ideas for combatting paternal PPD that have already been tried with success in Australia or the United Kingdom. (1) Pamphlets for men about paternal PPD and the normal stresses and changes that accompany caring for a new baby can be sent home with new mothers when they visit an obstetrics clinic for a postpartum exam. (2) Prenatal classes can be offered that are specifically designed for men only and that are taught by male instructors. (3) A telephone help line may be designated for counseling fathers with questions or depressive symptoms (Fletcher et al, 2006).

A recent review article about PPD in women listed a few promising research areas for treatments in addition to the standard antidepressants and psychotherapy. Included were (1) managing sleep disturbances, such as minimizing exposure to light that disrupts the sleep cycle by using blue-blocking glasses when getting up to care for the infant in the night, (2) massage, and (3) exercise (McCoy, 2011). Although these options have not been researched in men, they are relatively inexpensive and safe and could make helpful additions to or in some cases, perhaps even alternatives to, traditional pharmaco- and psychotherapy.

\section{Conclusions}

Paternal PPD is a relatively new field of study, but it is established that the rate of depression in men during the postpartum period exceeds that for men in the population at large, probably somewhere between $3-5 \%$. One important risk factor appears to be coincident PPD in the men's female partners, the new mothers. This disorder affects not only the men themselves, but also their children. In fact, the children of affected fathers may exhibit psychological disturbances and abnormalities even at the age of six or seven years. Although no perfect screening tool exists for detecting paternal PPD, the same EPDS that is used for women appears to be a valid instrument for screening men, particularly when a lower cutoff score is used. Treatments include antidepressants and psychotherapy and perhaps even some alternatives, but the main challenge at present is in convincing men that they need to seek help when they feel anxious, overwhelmed, angry, or sad. Educational and treatment programs that specifically target men experiencing PPD may make a significant contribution to the overall mental health of an entire family. Future research must focus on better education and public awareness about paternal PPD, better screening tools specifically for men, and treatment alternatives to psychotherapy or medications. 


\section{Appendix 1}

\section{Center for Epidemiologic Studies Depression Scale (CES-D)}

Below is a list of some of the ways you may have felt or behaved. Please indicate how often you've felt this way during the past week. Respond to all items.

\begin{tabular}{|c|c|c|c|c|}
\hline $\begin{array}{l}\text { Place a check } \\
\text { mark in the } \\
\text { appropriate } \\
\text { column. }\end{array}$ & $\begin{array}{l}\text { Rarely or none } \\
\text { of the time } \\
\text { (less than } \\
1 \text { day) }\end{array}$ & $\begin{array}{l}\text { Some or a } \\
\text { little of the } \\
\text { time } \\
\text { (1- } 2 \text { days) }\end{array}$ & $\begin{array}{l}\text { Occasionally or a } \\
\text { moderate } \\
\text { amount of time } \\
\text { (3-4 days) }\end{array}$ & $\begin{array}{l}\text { All of the time } \\
\text { (5-7 days) }\end{array}$ \\
\hline $\begin{array}{l}\text { 1. I was bothered } \\
\text { by things that } \\
\text { usually don't } \\
\text { bother me. }\end{array}$ & 0 & 1 & 2 & 3 \\
\hline $\begin{array}{l}\text { 2. I did not feel } \\
\text { like eating; my } \\
\text { appetite was } \\
\text { poor. }\end{array}$ & 0 & 1 & 2 & 3 \\
\hline $\begin{array}{l}\text { 3. I felt that I } \\
\text { could not shake } \\
\text { off the blues } \\
\text { even with help } \\
\text { from my family. }\end{array}$ & 0 & 1 & 2 & 3 \\
\hline $\begin{array}{l}4 . \text { I felt that I was } \\
\text { just as good as } \\
\text { other people. }\end{array}$ & 3 & 2 & 1 & 0 \\
\hline $\begin{array}{l}5 . \text { I had trouble } \\
\text { keeping my } \\
\text { mind on what I } \\
\text { was doing. }\end{array}$ & 0 & 1 & 2 & 3 \\
\hline $\begin{array}{l}\text { 6. I felt } \\
\text { depressed. }\end{array}$ & 0 & 1 & 2 & 3 \\
\hline $\begin{array}{l}\text { 7. I felt that } \\
\text { everything I did } \\
\text { was an effort. }\end{array}$ & 0 & 1 & 2 & 3 \\
\hline $\begin{array}{l}\text { 8. I felt hopeful } \\
\text { about the future. }\end{array}$ & 3 & 2 & 1 & 0 \\
\hline $\begin{array}{l}\text { 9. I thought my } \\
\text { life had been a } \\
\text { failure. }\end{array}$ & 0 & 1 & 2 & 3 \\
\hline 10. I felt fearful. & 0 & 1 & 2 & 3 \\
\hline $\begin{array}{l}\text { 11. My sleep was } \\
\text { restless. }\end{array}$ & 0 & 1 & 2 & 3 \\
\hline 12. I was happy. & 3 & 2 & 1 & 0 \\
\hline $\begin{array}{l}\text { 13. I talked less } \\
\text { than usual. }\end{array}$ & 0 & 1 & 2 & 3 \\
\hline
\end{tabular}




\begin{tabular}{|l|l|l|l|l|}
\hline $\begin{array}{l}\text { Place a check } \\
\text { mark in the } \\
\text { appropriate } \\
\text { column. }\end{array}$ & $\begin{array}{l}\text { Rarely or none } \\
\text { of the time } \\
\text { (less than } \\
1 \text { day) }\end{array}$ & $\begin{array}{l}\text { Some or a } \\
\text { little of the } \\
\text { time } \\
(1-2 \text { days })\end{array}$ & $\begin{array}{l}\text { Occasionally or a } \\
\text { moderate } \\
\text { amount of time } \\
(3-4 \text { days })\end{array}$ & $\begin{array}{l}\text { All of the time } \\
\text { (5-7 days) }\end{array}$ \\
\hline 14. I felt lonely. & 0 & 1 & 2 & 3 \\
\hline $\begin{array}{l}\text { 15. People were } \\
\text { unfriendly. }\end{array}$ & 0 & 1 & 2 & 3 \\
\hline 16. I enjoyed life. & 3 & 2 & 1 & 0 \\
\hline $\begin{array}{l}\text { 17. I had crying } \\
\text { spells. }\end{array}$ & 0 & 1 & 2 & 3 \\
\hline 18. I felt sad. & 0 & 1 & 2 & 3 \\
\hline $\begin{array}{l}\text { 19. I felt that } \\
\text { people disliked } \\
\text { me. }\end{array}$ & 0 & 1 & 2 & 3 \\
\hline $\begin{array}{l}\text { 20. I could not } \\
\text { "get going." }\end{array}$ & 0 & 1 & 2 & 3 \\
\hline
\end{tabular}

Source: Radloff, LS (1977). The CES-D scale: A self-report depression scale for research in the general population. Applied Psychological Measurement, 1:385-401.

Directions: Do not score if missing more than 4 responses. (1) For each item, look up your response and corresponding score (0-3). (2) Fill in the score for each item under the last column labeled "Score." (3) Calculate your Total Score by adding up all 20 scores.

Scoring Results: Total Score of 16 or higher is considered depressed. If your score indicates depression, see a health care/mental health professional for further evaluation and treatment. Bring these test results to your appointment.

\section{Appendix 2}

\section{Patient Health Questionnaire-9}

Over the last 2 weeks, how often have you been bothered by any of the following problems?

\begin{tabular}{|l|l|l|l|l|}
\hline $\begin{array}{l}\text { Use a check mark } \\
\text { to indicate your } \\
\text { answer. }\end{array}$ & Not at all & Several days & $\begin{array}{l}\text { More than half } \\
\text { the days }\end{array}$ & $\begin{array}{l}\text { Nearly every } \\
\text { day }\end{array}$ \\
\hline $\begin{array}{l}\text { 1. Little interest or } \\
\text { pleasure in doing } \\
\text { things. }\end{array}$ & 0 & 1 & 2 & 3 \\
\hline $\begin{array}{l}\text { 2. Feeling down, } \\
\text { depressed, or } \\
\text { hopeless }\end{array}$ & 0 & 1 & 2 & 3 \\
\hline $\begin{array}{l}\text { 3. Trouble falling } \\
\text { or staying asleep, } \\
\text { or sleeping too } \\
\text { much }\end{array}$ & 0 & 1 & 2 & 3 \\
\hline
\end{tabular}




\begin{tabular}{|c|c|c|c|c|}
\hline $\begin{array}{l}\text { Use a check mark } \\
\text { to indicate your } \\
\text { answer. }\end{array}$ & Not at all & Several days & $\begin{array}{l}\text { More than half } \\
\text { the days }\end{array}$ & $\begin{array}{l}\text { Nearly every } \\
\text { day }\end{array}$ \\
\hline $\begin{array}{l}\text { 4. Feeling tired or } \\
\text { having little } \\
\text { energy }\end{array}$ & 0 & 1 & 2 & 3 \\
\hline $\begin{array}{l}\text { 5. Poor appetite or } \\
\text { overeating }\end{array}$ & 0 & 1 & 2 & 3 \\
\hline $\begin{array}{l}\text { 6. Feeling bad } \\
\text { about yourself - } \\
\text { or that you are a } \\
\text { failure or have let } \\
\text { yourself or your } \\
\text { family down }\end{array}$ & 0 & 1 & 2 & 3 \\
\hline $\begin{array}{l}\text { 7. Trouble } \\
\text { concentrating on } \\
\text { things, such as } \\
\text { reading the } \\
\text { newspaper or } \\
\text { watching } \\
\text { television }\end{array}$ & 0 & 1 & 2 & 3 \\
\hline $\begin{array}{l}\text { 8. Moving or } \\
\text { speaking so } \\
\text { slowly that other } \\
\text { people could have } \\
\text { noticed? Or the } \\
\text { opposite - being } \\
\text { so fidgety or } \\
\text { restless that you } \\
\text { have been moving } \\
\text { around a lot more } \\
\text { than usual }\end{array}$ & 0 & 1 & 2 & 3 \\
\hline $\begin{array}{l}\text { 9. Thoughts that } \\
\text { you would be } \\
\text { better off dead or } \\
\text { of hurting } \\
\text { yourself in some } \\
\text { way }\end{array}$ & 0 & 1 & 2 & 3 \\
\hline
\end{tabular}

$=$ Total Score:

Developed by Drs. Robert L. Spitzer, Janet B.W. Williams, Kurt Kroenke and colleagues, with an educational grant from Pfizer Inc. No permission required to reproduce, translate, display or distribute. 


\section{Appendix 3}

\section{Edinburgh Postnatal Depression Scale}

How Are You Feeling?

As you have recently had a baby, we would like to know how you are feeling now. Please underline the answer which comes closest to how you have felt in the past 7 days, not just how you feel today.

Here is an example, already completed:

I have felt happy:

$\begin{array}{ll}- & \text { Yes, most of the time } \\ - & \text { Yes, some of the time } \\ \text { - } & \text { No, not very often } \\ \text { - } & \text { No, not at all }\end{array}$

This would mean: "I have felt happy some of the time" during the past week. Please complete the other questions in the same way.

\section{IN THE PAST SEVEN DAYS}

1. I have been able to laugh and see the funny side of things:

- As much as I always could

- Not quite so much now

- Definitely not so much now

- Not at all

2. I have looked forward with enjoyment to things:

- As much as I ever did

- Rather less than I used to

- Definitely less than I used to

- Hardly at all

*3. I have blamed myself unnecessarily when things went wrong:

- Yes, most of the time

- Yes, some of the time

- Not very often

- No, never

4. I have felt worried and anxious for no very good reason:

- No, not at all

- Hardly ever

- Yes, sometimes

- Yes, very often

*5. I have felt scared or panicky for no very good reason:

- Yes, quite a lot

- Yes, sometimes

- No, not much

- No, not at all

*6. Things have been getting on top of me:

- Yes, most of the time I haven't been able to cope at all 
- Yes, sometimes I haven't been coping as well as usual

- No, most of the time I have coped quite well

- No, I have been coping as well as ever

*7. I have been so unhappy that I have had difficulty sleeping:

- Yes, most of the time

- Yes, sometimes

- Not very often

- No, not at all

*8. I have felt sad or miserable:

- Yes, most of the time

- Yes, quite often

- $\quad$ Not very often

- No, not at all

*9. I have been so unhappy that I have been crying:

- Yes, most of the time

- Yes, quite often

- Only occasionally

- No, never

*10. The thought of harming myself has occurred to me:

- Yes, quite often

- Sometimes

- Hardly ever

- Never

Response categories are scored $0,1,2$, and 3 according to increased severity of the symptom. Items marked with an asterisk are reverse scored (i.e. 3, 2, 1 and 0). The total score is calculated by adding together the scores for each of the ten items. Users may reproduce the scale without further permission providing they respect copyright (which remains with the British Journal of Psychiatry) by quoting the names of the authors, the title and the source of the paper in all reproduced copies.

\section{Appendix 4}

The Gotland Scale for assessing male depression

Wolfgang Rutz, MD, PhD, Psychiatrist, Visby

Zoltan Rihmer, MD, PhD, Psychiatrist, Budapest

Arne Dalteg, PhD, Psychologist, Visby

English version: Per Bech, Lis Raabaek Olsen, Vibeke Norholm, Psykiatrisk Forskningsenhed, Hillerod

During the past month, have you or others noticed that your behavior has changed, and if so, in which way?

\begin{tabular}{|l|l|l|l|l|}
\hline & Not at all & $\begin{array}{l}\text { To some } \\
\text { extent }\end{array}$ & Very true & Extremely so \\
\hline $\begin{array}{l}\text { 1. Lower stress } \\
\text { threshold/more stressed out } \\
\text { than usual }\end{array}$ & 0 & 1 & 2 & 3 \\
\hline
\end{tabular}




\begin{tabular}{|c|c|c|c|c|}
\hline & Not at all & $\begin{array}{l}\text { To some } \\
\text { extent }\end{array}$ & Very true & Extremely so \\
\hline $\begin{array}{l}\text { 2. More aggressive, outward- } \\
\text { reacting, difficulties keeping } \\
\text { self-control }\end{array}$ & 0 & 1 & 2 & 3 \\
\hline $\begin{array}{l}\text { 3. Feeling of being burned } \\
\text { out and empty }\end{array}$ & 0 & 1 & 2 & 3 \\
\hline $\begin{array}{l}\text { 4. Constant, inexplicable } \\
\text { tiredness }\end{array}$ & 0 & 1 & 2 & 3 \\
\hline $\begin{array}{l}\text { 5. More irritable, restless and } \\
\text { frustrated }\end{array}$ & 0 & 1 & 2 & 3 \\
\hline $\begin{array}{l}\text { 6. Difficulty amking ordinary } \\
\text { everyday decision }\end{array}$ & 0 & 1 & 2 & 3 \\
\hline $\begin{array}{l}\text { 7. Sleep problems: sleeping } \\
\text { too much/too } \\
\text { little/restlessly, difficulty } \\
\text { falling asleep/waking up } \\
\text { early }\end{array}$ & 0 & 1 & 2 & 3 \\
\hline $\begin{array}{l}\text { 8. In the morning especially, } \\
\text { having a feeling of } \\
\text { disquiet/anxiety/uneasiness }\end{array}$ & 0 & 1 & 2 & 3 \\
\hline $\begin{array}{l}\text { 9. Overconsumption of } \\
\text { alcohol and pills in order to } \\
\text { achieve a calming and } \\
\text { relaxing effect. Being } \\
\text { hyperactive or blowing off } \\
\text { steam by working hard and } \\
\text { restlessly, jogging or other } \\
\text { exercises, under- or } \\
\text { overeating }\end{array}$ & 0 & 1 & 2 & 3 \\
\hline $\begin{array}{l}10 . \text { Do you feel your } \\
\text { behavior has altered in such } \\
\text { a way that neither you } \\
\text { yourself nor others can } \\
\text { recognize you, and that you } \\
\text { are difficult to deal with? }\end{array}$ & 0 & 1 & 2 & 3 \\
\hline $\begin{array}{l}\text { 11. Have you felt or have } \\
\text { others perceived you as } \\
\text { being gloomy, negative or } \\
\text { characterized by a state of } \\
\text { hopelessness in which } \\
\text { everything looks bleak? }\end{array}$ & 0 & 1 & 2 & 3 \\
\hline $\begin{array}{l}\text { 12. Have you or others } \\
\text { noticed that you have a } \\
\text { greater tendency to self-pity, } \\
\text { to be complaining or to seem } \\
\text { "pathetic"? }\end{array}$ & 0 & 1 & 2 & 3 \\
\hline
\end{tabular}




\begin{tabular}{|l|l|l|l|l|}
\hline & Not at all & $\begin{array}{l}\text { To some } \\
\text { extent }\end{array}$ & Very true & Extremely so \\
\hline $\begin{array}{l}\text { 13. In your biological family, } \\
\text { is there any tendency toward } \\
\text { abuse, depression/dejection, } \\
\text { suicide attempts or } \\
\text { proneness to behavior } \\
\text { involving danger? }\end{array}$ & 0 & 1 & 2 & 3 \\
\hline
\end{tabular}

Total Score:

0-13: No signs of depression.

13-26: Depression possible. Specific therapy, including psychopharmacological, possibly indicated.

26-39: Clear signs of depression. Specific therapy, including psychopharmacological, clearly indicated.

\section{References}

American Psychiatric Association. Diagnostic and Statistical Manual of Mental Disorders, Fourth Edition, Text Revision. Washington, DC: American Psychiatric

Association, 2000.

Condon JT, Boyce P, Corkindale CJ. (2004). The First-Time Fathers Study: a prospective study of the mental health and wellbeing of men during the transition to parenthood. Aust N Z J Psychiatry 38:56-64.

Cox JL, Holden JM, Sagovsky R. (1987). Detection of postnatal depression. Development of the 10-item Edinburgh Postnatal Depression Scale. Br J Psychiatry 150:782-786.

Cuijpers P. (2008). Psychological treatment of postpartum depression: a meta-analysis. J Clin Psychol 64:103-18.

Depression Facts and Statistics. (2009) "Clinical Depression" http://www.depressionperception.com/depression/depression_facts_and_statisti cs.asp\#clinical (Accessed August 16, 2011).

Fletcher RJ, Matthey S, Marley CG. (2006). Addressing depression and anxiety among new fathers. MJA 185(8):461-3.

Lai BP, Tang AKI, Lee DTS, Yip ASK, Chung TKH. (2010). Detecting postnatal depression in Chinese men: a comparison of three instruments. Psychiatry Res 180(2-3): 80-5.

Madsen SA, Juhl T. (2007). Paternal depression in the postnatal period assessed with traditional and male depression scales. JMHG 4(1):26-31.

Male Depression: Understanding the Issues. www.mayoclinic.com/health/maledepression/MC00041. Accessed August 10, 2011.

Matthey S, Barnett B, Kavanagh DJ, Howie P. (2001). Validation of the Edinburgh Postnatal Depression Scale for men and comparison of item endorsement with their partners. J Affect Disord 64:175-184.

McCoy SJB. (2001). Postpartum depression: An essential overview for the practitioner. Southern Med J 104(2):128-132.

Paulson JF, Bazemore SD. (2010). Prenatal and postpartum depression in fathers and its association with maternal depression: a meta-analysis. JAMA 303(19):1961-9.

Pearlstein T, Howard M, Salisbury A, Zlotnick C. Postpartum depression. (2009) Am J Obstet Gynecol 200:357-64. 
Radloff, LS. (1977). The CES-D scale: A self-report depression scale for research in the general population. Applied Psychological Measurement 1:385-401.

Ramchandani PG, Stein A, O'Connor TG, Heron J, Murray L, Evans J. (2008). Depression in Men in the Postnatal Period and Later Child Psychopathology: A Population Cohort Study. J Am Acad Child Adolesc Psychiatry 47(4):390-398.

Schumacher M, Zubaran C, White G. (2008). Bringing birth-related paternal depression to the fore. Women Birth 21(2): 65-70.

Sit DKY, Wisner KL. (2009). Identification of postpartum depression. Clin Obstet Gynecol. 52:456-68.

Veskrna, L. (2010). Peripartum depression - does it occur in fathers and does it matter? JMH 7(4):420-430.

Zierau, F., Bille, A., Rutz, W., \& Bech, P. (2002). The Gotland male depression scale: A validity study in patients with alcohol use disorder. Nordic Journal of Psychiatry, 56, 265-271. 


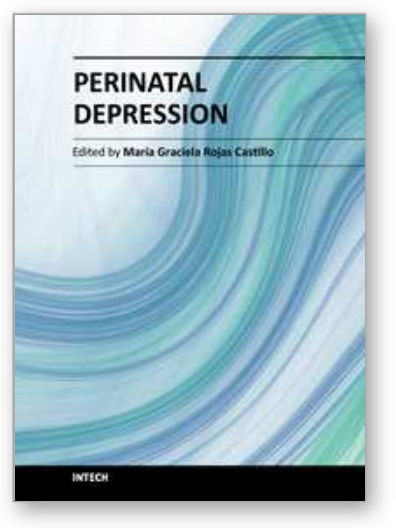

\author{
Perinatal Depression \\ Edited by Dr. María Graciela Rojas Castillo
}

ISBN 978-953-307-826-7

Hard cover, 190 pages

Publisher InTech

Published online 20, January, 2012

Published in print edition January, 2012

This book presents ten chapters that give us important information about epidemiological, biological, clinical and psychological aspects of common mental disorders during pregnancy and in the postnatal period. Some of the issues covered in this book are: detecting postnatal depression using different instruments at the right time, which is very important to avoid the negative effects on the children of depressed mothers; understanding the impact of anxiety and depression during pregnancy and in the postnatal period; biological issues of perinatal anxiety and depression; epidemiological information about perinatal mental health problems among minorities, like immigrant population and underserved rural women. Some information is also provided on postnatal depression in men, which is frequently overlooked.

\title{
How to reference
}

In order to correctly reference this scholarly work, feel free to copy and paste the following:

Sarah J. Breese McCoy (2012). Postpartum Depression in Men, Perinatal Depression, Dr. María Graciela Rojas Castillo (Ed.), ISBN: 978-953-307-826-7, InTech, Available from:

http://www.intechopen.com/books/perinatal-depression/postpartum-depression-in-men-

\section{INTECH}

open science | open minds

\section{InTech Europe}

University Campus STeP Ri Slavka Krautzeka 83/A 51000 Rijeka, Croatia Phone: +385 (51) 770447

Fax: +385 (51) 686166 www.intechopen.com

\section{InTech China}

Unit 405, Office Block, Hotel Equatorial Shanghai No.65, Yan An Road (West), Shanghai, 200040, China 中国上海市延安西路65号上海国际贵都大饭店办公楼405单元 Phone: +86-21-62489820

Fax: $+86-21-62489821$ 
(C) 2012 The Author(s). Licensee IntechOpen. This is an open access article distributed under the terms of the Creative Commons Attribution 3.0 License, which permits unrestricted use, distribution, and reproduction in any medium, provided the original work is properly cited. 